\title{
Intertextuality Between T. S Eliot and Al Sayyab's Poetry
}

\author{
Mohamed Ayed Ayasrah ${ }^{1} \&$ Mohd Nazri Latiff Azmi ${ }^{1}$ \\ ${ }^{1}$ Universiti Sultan Zainal Abidin (UniSZA), Malaysia \\ Correspondence: Mohamed Ayed Ayasrah, Universiti Sultan Zainal Abidin (UniSZA), Malaysia. E-mail: \\ ayasrah@gmail.com
}

Received: January 24, 2019 Accepted: February 20, 2019 Online Published: April 6, 2019

doi:10.5539/ijel.v9n3p78

URL: https://doi.org/10.5539/ijel.v9n3p78

\begin{abstract}
The purpose of this study is to shed light on 'intertextuality' as a cross cultural technique between modern Arabic and English poetry with reference to T. S Eliot and Al Sayyab. It aims to uncover the intertextual aspects of 'allusion', 'symbols and myths', 'irony', 'the objective equivalent', 'conceptual metaphor' and 'impersonality' between Eliot and Al Sayyab and the impact of Eliot's thoughts, themes, expressions and style on Al Sayyab's. However, the study reveals that the strategy of intertextuality takes a one-way direction, i.e., from Eliot to Al Sayyab, and Eliot's fingerprints are quite manifest in Al Sayyab's poetry. Moreover, although some of Eliot's key expressions, ideas, symbols, myths and themes are borrowed by Al Sayyab, he could professionally use intertextuality and maintain his illustrious style.
\end{abstract}

Keywords: intertextuality, ambiguity, the objective correlative, impersonality, conceptual metaphors

\section{Introduction}

Although intertextuality has been broadly researched, there is a clear lack in studying it as a cross cultural phenomenon in modern poetry. To fill part of this gab, this study investigates intertextuality as a cross cultural phenomenon between modern Arabic and English poetry with reference to Al Sayyab and T. S Eliot's poetry. This factor strengthens the study and lists it in the few studies which explore this phenomenon in the realm of modernism. The study also aims to identify and analyse the aspects of intertextuality between Eliot and Al Sayyab beside identifying the extent of Eliot's influence on Al Sayyab's works. Lastly, it is worth mentioning that to simplify the process of comparison between the two poets the study adopts the English translation of Al Sayyab's Rain Song which is done by Lena Jayyusi and Christopher Middleton (Al-Sayyab, 1987).

\subsection{Previous Related Studies}

Intertextuality has been widely investigated nonetheless few researchers have explored it in modern Arabic and English poetry. For instance, Sultan and Rai'a (2007) study intertextuality from only the perspective of the themes of death, sterility and aridity in Eliot's The Waste Land as a case study. Also, Nasi (2012) explores only the mythic method and intertextuality in T. S. Eliot's poetry. Abood (2015) focuses on past and modernity of intertextuality in Eliot's The Waste Land. Besides, Sirhan (2014) concentrates on expectations of intertextuality in T. S. Eliot's poetry shedding light on the use of epigraph. It is noticed that most previous studies of intertextuality in modern poetry emphasis on how preceding English authors affect and inspire T. S Eliot. However, the present study explores intertextuality between two different languages and so different cultures i.e., (the East and West) with reference to Al Sayyab and Eliot in terms the aspects of 'ambiguity', 'symbols and myths', 'irony', 'the objective equivalent', 'conceptual metaphor' and 'impersonality'.

\section{Method of Analysis}

After studying the main poems like Eliot's The Waste Land and Al Sayyab's The Rain Song the central cross points between the poets are identified and explored to extract the shared poetic scenes. Moreover, the aspects of intertextuality between the two poets are characterised to draw the borders of the comparison story of this phenomenon. Because of the nature of the study which deals with literary texts, the qualitative data analysis method is adopted to analyse its data. Consequently, the mutual intertextual scenes are recognized and classified under the suitable pattern of 'ambiguity', 'symbols and myths', 'irony', 'the objective equivalent', 'conceptual metaphor' and 'impersonality'. Each of these aspects is investigated through studying and analysing samples from Eliot and Al Sayyab's poetry. Finally, the outcomes are concluded and discussed to reach to final results. 


\section{What Is Intertextuality?}

Intertextuality is simply defined as the effectiveness of one text on another, particularly in literature. Originally, it comes from Latin 'intertexto' which means intermix. Allen (2011) declares that although it is an ancient literary strategy, intertextuality is initially inserted in 1966 by Julia Kristeva who states that many ideas, thoughts and meanings are intersectional. Additionally, she claims that there is not a new, original text because texts are intertextual and each one has another inside. Kristeva also believes that a single author can not create the literary work alone since any literary text is always affected by other previous texts (Allen, 2011).

Gadavanij (2002) declares that intertextuality is a tool that builds up an overlapping between texts and produces an atmosphere of comprehension among different texts to enrich new literary works and affect the audience relying on previous related knowledge and experiences. Authors use intertextuality as a central device in composing new poems, stories, novels, plays and even spoken texts. The author's literary concepts are not conveyed to the audience as smooth as of everyday language. What distinguishes the literary from everyday language is its eloquence which mostly creates invisible meanings and hides indirect messages; such strategy is imparted to the author and his audience via another text (Fabb, 2010). However, intertextuality can be produced into several forms as plagiarism, quotation, citation, interpretation, pastiche, insinuation or spoof (Hallo, 2010).

Intertextuality is branched into three different domains: compulsory, facultative and incidental. The main elements that identify each domain are the importance of the original text and the aim of the author. It is worth mentioning here that two or three of the domains can come in one text (Fitzsimmons, 2013). The compulsory domain is manifested when the author is obliged to link between the two texts in a way or another to enable the reader to comprehend the intended meaning which is never integral without the prior hypertext. The facultative domain is not as active as the compulsory, but it signifies that there is a link between the two texts. Nonetheless, this domain is not essential to get the intended meaning of the text, and it is also not intentional by the author who may utilise it as a tribute for the prior authors. In the incidental domain, the one who founds the interrelation between the two texts is the reader, not the writer. In this domain, the reader depends on his own experience to create a link between the text and a prior one though there may not be any intended links by the author (Fitzsimmons, 2013).

\section{Eliot and Al Sayyab}

Doubtless, Thomas Stearns Eliot, (T. S Eliot) henceforth and Bader Shaker Al Sayyab, (Al Sayyab) henceforth, are considered ones of the most famous pioneers of modernism movement in both English and Arabic poetry. Actually, by introducing the free verse in his language, each of them is considered the starter of the modernism movement. However, the two poets were disappointed when they find themselves in a world full of killing, destruction, sadness, injustice, interruption, soulless bodies, frequent wars, corruption and inhumanity. In such environment, the direct expression of the unconscious will not be poetry so what should the poet do? He starts building his own convenient, vivid realm by using effective strategies like symbolism, intertextuality, metaphors and myths (Howard, 2015). Such strategies help the poet to be capable of uncovering the shortage of the necessary poetic elements in addition to utilise those tools against the dominant logic of gold and iron.

Eliot metaphorically sees modern life as a wasteland because it is soulless, corrupted, barren, gloomy, miserable and hopeless. This frustration is not found arbitrarily. It actually sneaks into his heart and mind through the ages of suffering and melancholy (Ayassrah \& Alidmat, 2017). Al Sayyab was not more fortunate than Eliot; he faced a series of hard struggles such as being an orphan, acute diseases, interceptions by the Iraqi government, job loss, denied from the country and corruption in Iraq.

\subsection{Eliot's Poetry Influence}

The massive influence of Eliot's poetry invades most of the modern Arab poets who celebrate it because of its outstanding features and its elegant rhetorical language. A lot of Arab critics introduce Eliot as the most effective source of modern Arabic poetry. Whereas, some Arabic critics nibble his poetry since it is the colonisers' poetry. Besides, they considered the existence of his poetry in modern Arabic literature is a matter of cultural colonisation.

Badawi (1975) states that the influence of Eliot's on the Arabic literature initiated in the early of 1930s; this was originally by the first translators who conveyed many of his thoughts to the Arabic literary works. Notably, the vast majority of the studies concerning Eliot in Arab world emphasis on the topic of one-side effect, namely his effect on modern Arabic poetry like Al Sayyab's. Al Sayyab is considered one of the first pioneers who established the hybrid Arabic literature by transferring many aspects of the western experience to the world of the Arabic literature via intertextuality and translation. 


\subsection{Intertextuality Between Al Sayyab and Eliot}

Undoubtedly, intertextuality between Al Sayyab and Eliot takes a one-way direction, namely from Eliot to Al Sayyab; that is just because Al Sayyab was mostly affected by Eliot's 'The Waste Land' which was published in 1922; i.e. before Al Sayyab was born in 1926.

Ones of the primary sources of intertextuality between Eliot and Al Sayyab are the shared attitudes about traditional poetry. Al Sayyab and Eliot have almost similar opinions about the traditional heritage. They consider that the past heritage is fundamental in modern poetry though that they call to resist the old restrictions, styles and limitations. Both of them claim that modern poets should rebel against the faults of old traditional thoughts and style because they are too old to be used nowadays. Although they are against old traditional style in poetry, they believe that the past heritage has to be reviewed to avoid its badness. However, they attempt to combine between historical and present thoughts via utilising symbolism and inserting old myths in modern poetry which could be the first step of their intertextuality trip.

Apparently, they believe that the modern world is not a convenient environment for their poetry which seeks to mirror the real life of the society; at the same time, they cannot confine their poetic emotions nor express them artificially or directly. Consequently, both of them resort to myth to get rid of the restrictions of the traditional poetry and the unpoetic modern life and to be able to bring poetry9 into the modern world by creating a fertile environment for their thoughts and emotions. However, they escape to the realm of myths and symbolism in order to draw the attention of their audiences to the idea that the unpleasant, disgraceful life has to be better than what it seems. Eliot illustrated the modern poets' duty as follows:

What we have to do is to bring poetry into the world in which the audience lives and to which it returns when it leaves the theatre; not to transport the audience into some imaginary world totally unlike their own, an unreal world in which poetry can be spoken... we should not be transported into an artificial world (Eliot 1953, p. 33).

Al-Sayyab maintains that modern poets should rebel against the faults of old traditional thoughts and style because they are too old and inconvenient. Nonetheless, he claims that the past heritage has to be reviewed only to avoid its badness. Furthermore, he admonishes those who claim that old Arabic poetry is perfect and it is considered the archetype; he also blames those who compare the old heritage to the modern requirements to prove that the past heritage is not valid to the current time. However, Eliot is one of those who could mix the old with the present by using myths and symbolism mentioned in previous old literary works (Litz 2008).

Kadhim (2004) states that despite Eliot's calls for separating between literature and policy, he sustains the British colonisation. More to the point, he claims that The Waste Land can be seen from another angle in which it presents the West as the central part of the old and new worlds assuming that there are no other histories. Consequently, the broad goals of this poem may not only be depicting the miserable life of the modern world of the West during and after WWI.

Al Sayyab's acquaintance with Arabic and English literature helps him widening his knowledge and originating modern, hybrid poetry. 'Hybrid poetry' is considered a kind of a poetic flaw in traditional Arabic literature because borrowing from or simulating another writer means doing theft or plagiarism. However, some critics believe that committing plagiarism is a smaller offence when comparing it to hybrid, intertextuality and influence; that is because the poet means to commit plagiarism, but the others are committed commonly and unintentionally (Alhusami, 2017).

\subsubsection{Ambiguity}

Ambiguity can be defined as giving more than one meaning of a word, expression, action, or situation (Sutton-Smith, 2009). This feature makes the image unclear since it can be interpreted in several ways. Ambiguity is one of the features of modern poetry that makes its language distinguished from other literary types. However, this feature is prominent in Eliot and Al Sayyab's Poetic language. Eliot's The Waste Land and Al Sayyab's The Rain Song are fine examples of this technique. The strategy of ambiguity appears clearly in the first stanza of Eliot's The Waste Land. This stanza includes the idea of infertility in which spring is mockingly used as a symbol of dryness instead of fertility.

April is the cruelest month, breeding

Lilacs out of the dead land, mixing

Memory and desire, stirring

Dull roots with spring rain. 
Likewise, Al Sayyab, in 'Al Sindibad's Town' poem, uses the same topic of infertility where spring is scornfully used as a symbol of dryness instead of fertility.

Oh Spring, what has afflicted you?

You came with no rain,

.... with no flowers, .... with no fruit.

\subsubsection{Ancient Myths}

Although Eliot and Al Sayyab are against the styles and restrictions of the past, they could expertly combine between the past and present by using some ancient myths. For example, in The Waste Land Eliot uses the myth of the Athenian princess who is converted to a singing nightingale that is singing and trying to tell others his tragic story but no one could understand him; he says:

The change of Philomela, by the barbarous king

So rudely forced, yet there the nightingale

Filled all the desert with inviolable voice

Simultaneously, Al Sayyab intertextually uses the myth of 'Thammuz, and Ishtar', and 'Osiris and Isis'. By using different kinds of myths in his poems, Al Sayyab shows the audience that he is as masterful as Eliot in employing this strategy. He could use the myths of death and resurrection like Tammuz and Ishtar, the myth of sorrows like Isis and Oedipus, and the myths of love such like Eurydice and Orpheus in addition to borrowing some myths used by Eliot.

Another noticeable and intertextual ancient myth is the drowned Phoenician sailor who sank in water and died. This ancient myth is utilised by Eliot to laments his close French friend 'Jean Ferdinand' who was killed in WWI and his body drowned in the Dardanelles Strait where his bones were scattered on the seafloor after they had been floating for a while. Eliot says "the drowned Phoenician Sailor; those are pearls that were his eyes". Correspondingly, Al Sayyab imitates Eliot in employing the same myth when he says "the explorer of the ocean, slept in the depths; pearls from his eyeballs are sold by merchants". Besides, in The Rain Song, Al Sayyab reuses the same myth when he states 'And the skeletons of miserable drowned emigrants" and thirdly when he says:

The Gulf casts its abundant gifts on the sand

Foam, shells and the bones of an immigrant

Who drank death

At the bottom of the Gulf.

In the poem of 'Vision of 1956' Al Sayyab has employed various old symbols and myths like Zeus, Ganymede, Thammuz, Baal, Ishtar, Mary, Lazarus, Judas, and Hafsa:

$O$, strange divine eagle

Crucifying my eyes as the Christ, Tammuz,

My soul is ripping

Ishtar is on a trunk of the tree ....

4.2.3 Irony

Irony can be defined as a rhetorical technique where the surface or expected meaning is different from the underlying actual one. Eliot and Al Sayyab capably employ the strategy of irony in their poetry. For example, the titles of their poems The Rain Song and The Waste Land are obvious examples of this technique. Both of them employ the theme of rain as a source of tears, sorrow and death instead of rebirth, happiness, freedom and hope. In The Waste Land Eliot talks about the dryness of soul and morals of the European during and after WWI, not about the real wasteland. Moreover, in 'The Game of Chess' the second section of The Waste Land, Eliot ironically compares between the upper and lower classes of the European society. Likewise, when we read 'Your eyes are two palm tree forests' in The Rain Song, we may think that Al Sayyab depicts his beloved whereas he ironically describes his home 'Iraq' and its palm trees.

\subsubsection{The Objective Correlative}

The objective correlative can be defined as some objects, images, or events joined to evoke a certain feeling. In The Waste Land, Eliot adopts the theme of 'water' as an 'objective correlative' to express the soul and ethical drought in the modern world metaphorically. Correspondingly, Al- Sayyab employs the same strategy in The 
Rain Song to convey almost the same idea but via using the theme of 'rain' as an 'objective correlative instead of 'water'. It has been observed a clear correlation between the core theme of the two poems: 'rain' in The Rain Song and 'water' in The Waste Land; both of rain and water are usually symbols of life, rebirth and hope. Contrariwise of the traditional ideas about 'water' and 'rain', the two poets often use the conceptual metaphors to show the paradox of these themes; they ironically portray these symbols as means of destruction and death.

It is perceived that water and rain are quite frequent and permeated in the two poems either directly or by mentioning related terms as winter clouds, mist, wet, thunder, lightning, river, snow, drink, drown, pours, drop waves and sea. Eliot titles the fourth part of his poem as 'Death by Water' where he laments his close friend who drowned in water; besides the last section is titled as 'What the Thunder Said' in which thunder is usually related to rain. Al Sayyab, however, titles the whole poem as The Rain Song and almost every stanza of the poem has a word or more related to rain. Moreover, 'water' and 'rain' sometimes come in the form of a regular musical rhythm as 'drip drop drip drop' in The Waste Land which is imitated by Al Sayyab in The Rain Song as 'rain, rain, rain'.

\subsubsection{Impersonality}

Impersonality is the technique when the poet does not introduce his own 'personality', but he expresses himself through the ideas and characters of his poetry. This strategy was originally introduced in the modern poetry by $\mathrm{T}$. S Eliot (McCormick, 2018). As an instance, Litz (2008) debates that the personality of the poet should not appear in his poetic scenes because the invisible elements inside the body of the modern poem refer to him.

Impersonality refers to pure objectivity, but subjectivity refers to the writer's emotions of the topic of the literary work. Subjectivity mirrors the poet's character and shows the reader how far the poet's 'I' is noted in the scenes of the poem. Moreover, a few critics believe that the poem is impersonal if it is empty of the first personal pronouns like I and me Litz (2008). Nonetheless, the poetic scene can never be achieved without the poet's emotions, so Eliot and Al Sayyab use myths and symbolism to express their feelings indirectly. Moreover, instead of using the poet's 'I' in the poetic scene, they personify themselves in animate and inanimate things so that their poems are almost empty of the first personal pronouns like I and me.

\subsubsection{The Conceptual Metaphors}

Eliot and Al Sayyab's poetry is overcrowded with conceptual metaphors that almost every stanza of their poetry has at least one conceptual metaphor. For example, the title of Eliot's Waste Land is itself a metaphor in which he compares the dryness of morals and emotions of Europeans after WWI to the dryness of the wasteland. The title of Al Sayyab's The Rain Song is also a metaphor where he compares rain to a human being who can sing. Another instance appears at the first stanza when Eliot starts his Waste Land depicting April as the cruellest month where he compares April to a cruel person. By this metaphorical scene, Eliot breaks down the traditional European thoughts related to April which is usually the symbol of rebirth, hope and love, not only in Europe but also in all over the world. Simulating Eliot's elegant style, Al Sayyab starts his Rain Song by a delightful, unconventional, romantic and metaphorical scene "Your eyes are two palm tree forests", which shocks the reader when he discovers it is revolutionary and political. Al Sayyab's beloved and mother are not real women; they are metaphorical symbols of his home 'Iraq'.

Moreover, in the metaphorical scene "that corpse you planted ... has it begun to sprout" of The Waste Land Eliot reveals his deep sorrow of losing his closest friend by comparing his burial corpse to a plant seed which is expected to sprout soon. He cannot imagine life without this friend, so he illogically rejects this reality by regenerating the hope of meeting him soon when he gets up of his death. Al Sayyab who lost his mother in his childhood imitates Eliot when he metaphorically compares her death to sleeping as "sleeping her death", he tries to create a glimmer of hope that she might get up one day since she is sleeping not dead. Although Al Sayyab seems to be optimistic in this scene, he is not illogical when stating "she must come back again". He may try to escape from the painful of his real life and to show his yearning and nostalgia to his mother who is a symbol of Iraq.

Furthermore, many metaphorical intertextual scenes appear between them in several places. In his Waste Land, Eliot humanizes the wind as he states "What is that noise? The wind under the door". Those verses are borrowed by Al Sayyab when he says "The door was not knocked on, but the wind". Moreover, Eliot's metaphorical scene "I have measured out my life with coffee spoons" is imitated by Al Sayyab once he says "I measure my hours with cups". 


\section{Conclusion}

In a nutshell, Eliot's fingerprints appear clearly in Al Sayyab's poetry in many thoughts, themes, techniques and expressions. Intertextuality is apparent in Al Sayyab's poetry where he borrows some of Eliot's main themes like life, death, water, dryness and sadness. Also, it appears in Al Sayyab's main poetic techniques that are copied from Eliot like 'allusion', 'symbols and myths', 'irony', 'the objective equivalent', 'conceptual metaphor' and 'impersonality'. Furthermore, some of Eliot's central terms and expressions arise in Al Sayyab's poetry such as evening yawn, the warmth of winter, the gulf, the drowned sailor, the drowned bones, the two eyes, the planted corpus, water and rain. Moreover, Al Sayyab is still innovator and independent even though he profoundly emulates Eliot's style when infringing the old traditional style of Arabic poetry, using myths intensely, utilising symbolism, and being pessimistic.

Finally, it can be said that although intertextuality has often been explored in previous research, some of its important aspects have not been recognized or examined. For example, investigating intertextuality as cross-cultural phenomenon between modern Arabic and English poetry has not been sufficiently specified. However, this research investigates the influence of Eliot's poetry on Al Sayyab's so it contributes in treating part of the problem by presenting some data to students, researchers and scholars who may deal with this topic. The results also show that intertextuality may help the poet to benefit from others and create his own distinguished style like Al Sayyab.

\section{References}

Abood, L. A. R. (2015). History and Modernity A Study of Intertextuality in Eliot's (The Waste Land). Al-Ameed Journal, 4(4), 45-61.

Alhusami, M. A. H. (2017). Impersonality, Traditional Heritage and Intertextuality: A Comparative Study between Salah Abd al-Sabur, Badr Shakir Al-Sayyab and TS Eliot. International Journal of Applied Linguistics and English Literature, 6(7), 220-226. https://doi.org/10.7575/aiac.ijalel.v.6n.7p.220

Allen, G. (2011). Intertextuality. Routledge. https://doi.org/10.4324/9780203829455

Al-Refai, H. (2013). Myth and other Folkloric Elements in Al-Sayyaab's poetry: Folkloristic Review. Arab Journal for the Humanities, 31(121).

Al-Sayyab, B. S. (1987). Rain Song." Lena Jayyusi and Christopher Middleton, trs.

Ayassrah, M. A. I., \& Alidmat, A. O. (2017). Metaphor as a Means of Pessimism in English Poetry. International Journal of English Linguistics, 7(5), 135. https://doi.org/10.5539/ijel.v7n5p135

Badawi, M. M. (1975). A Critical Introduction to Modern Arabic Poetry. Cambridge: Cambridge UP. https://doi.org/10.1017/cbo9780511554124

Eliot, T. S. (1953). The tree voices of poetry. Cambridge University Press. PMCid:PMC2024043

Fabb, N. (2010). Is literary language a development of ordinary language?. Lingua, 120(5), 1219-1232. https://doi.org/10.1016/j.lingua.2009.07.007

Fitzsimmons, J. (2013). Romantic and contemporary poetry: readings. Retrieved from CQUniversity e-courses, LITR19049-Romantic and Contemporary Poetry http://moodle. cqu. edu. au.

Gadavanij, S. (2002). Intertextuality as discourse strategy: The case of no-confidence debates in Thailand. Leeds working papers in linguistics and phonetics, 9, 35-55.

Hallo, William W. (2010) The World's Oldest Literature: Studies in Sumerian Belles-Lettres (Vol. 35). Brill. https://doi.org/10.1017/s0041977x11000097.

Howard, D. R. (2015). Three Temptations: Medieval Man in Search of the World. Princeton University Press. https://doi.org/10.1515/9781400879298.

Kadhim, H. N. (2004). The Poetics of Anti-Colonialism in the Arabic Qasidah. Leiden: Brill. PMCid:PMC1719994

Litz, A. W. (eds). (2008). The Cambridge History of Literary Criticism: Modernism and the New Criticism. Vol. 7. Cambridge: Cambridge UP. https://doi.org/10.1017/CHOL9780521300124

McCormick, J., \& Core, G. (2018). TS Eliot and His Impersonal Theory of Art. In Sallies of the Mind (pp. 15-22). Routledge. https://doi.org/10.4324/9781351291408-2.

Mitchell, J. C. (2008). TS Eliot's search for Eden: An examination of the mythic pattern of expulsion, exile, and redemption. California State University, Dominguez Hills. 
Nasi, M. (2012). The mythic method and intertextuality in TS Eliot's poetry. European Scientific Journal, 8(6).

Sirhan, Q. (2014). Anticipations of Intertextuality in T. S. Eliot's Poetry with Special Reference to his Use of the Epigraph.

Sultan, H. S., \& Rai'a, A. (2007). Intertextuality: The Themes of Death, Sterility and Aridity in Eliot's The Waste Land as A Case Study. Buhuth Mustaqbaliya Scientific Periodical Journal, 4(1), 7-32.

Sutton-Smith, B. (2009). The ambiguity of play. Harvard University Press.

\section{Copyrights}

Copyright for this article is retained by the author, with first publication rights granted to the journal.

This is an open-access article distributed under the terms and conditions of the Creative Commons Attribution license (http://creativecommons.org/licenses/by/4.0/). 